\title{
Isolation of Acidic Mucilage from the Outer Seed Coat of Shaddock (Citrus grandis Osbeck) and Evaluation of Its Functional Properties
}

\author{
Heng-Long Wang1,2*, Wei-Yu Chen ${ }^{1}$, Pei-Jung Tsai ${ }^{2}$, Chen-Yi Lin'2, Yuan-Ting Hsu', \\ Li-Feng Chen', Wei-Zhi Wu1, Wan-Chi Wang1, Wen-Jen Yang1, Chao-Lin Chang ${ }^{3}$, \\ Wei-Tung Liao ${ }^{4}$ \\ ${ }^{1}$ Department of Life Sciences, National University of Kaohsiung, Taiwan \\ ${ }^{2}$ Institute of Biotechnology, National University of Kaohsiung, Taiwan \\ ${ }^{3}$ Food Industry Research and Development Institute, Taiwan \\ ${ }^{4}$ Department of Chemical and Materials Engineering, Southern Taiwan University of Science and Technology, \\ Taiwan \\ Email: "hlwang@nuk.edu.tw
}

Received 3 March 2016; accepted 16 April 2016; published 19 April 2016

Copyright (C) 2016 by authors and Scientific Research Publishing Inc.

This work is licensed under the Creative Commons Attribution International License (CC BY).

http://creativecommons.org/licenses/by/4.0/

c) (i) Open Access

\begin{abstract}
After water imbibition, the outer layer seed coat of shaddock (Citrus grandis Osbeck) produces transparent gel-like mucilage (MSS), but its characteristics have never been studied before. This study aimed to assess the physico-chemical and functional properties of MSS. Extractions of MSS with deionized water at room temperature yielded about $3.5 \%$ based on the dry weight of seed. The major components were neutral sugars and uronic acids in the amounts of $33.5 \%$ and $49.6 \%$, respectively. The acidic nature of MSS was confirmed by ruthenium red staining. Its water holding capacity and viscosity were $44.53 \mathrm{~g} \cdot \mathrm{g}^{-1} \mathrm{DW}$ and $1660 \mathrm{cP}$ at $10 \mathrm{~g} / \mathrm{L}$, respectively. MSS showed a weak quenching activity against DPPH radical, and moderate ferrous ion-chelating and superoxide anion radical scavenging activities, with $\mathrm{IC}_{50}$ value of $1.5 \mathrm{~g} / \mathrm{L}$ and $1.1 \mathrm{~g} / \mathrm{L}$, respectively. A methyl thiazolyl tetrazolium (MTT) assay demonstrated that MSS significantly stimulated the viability of mouse skin fibroblasts (NIH/3T3) at $5-300 \mathrm{mg} / \mathrm{L}$. These results impart the potential usefulness of the MSS to food, cosmetics and other applications.
\end{abstract}

\footnotetext{
${ }^{*}$ Corresponding author.
} 


\section{Keywords}

\section{Antioxidation, Cell Viability, Shaddock Seed, Viscosity, Water Holding Capacity}

\section{Introduction}

Many angiosperms, including Brassicaceae, Solanaceae, Linaceae, and Plantaginaceae, among others, produce a pectinaceous mucilage layer in their outer seed coat, known as myxospermy [1] [2]. This seed mucilage is thought to play many important roles, including to decrease the rate of water loss and increase the moisture supply to the seed [3] [4], maintain seed viability under harsh desert conditions [5], initiate or ensure seed germination [6], and prevention of seed dispersal by adherence to soil, and promotion of seed spreading by attachment to animals [7], among others. Evidently, the seed mucilage presents some special physical and chemical properties to achieve the aforementioned ecological and physiological roles.

Mucilage is a complex heterogeneous polysaccharide. Polysaccharides have emerged as an important class of bioactive natural products [8] and widely used in food, cosmetics, textiles, and pharmaceutical systems for various purposes, such as thickener, stabilizer, emulsifier, excipient, and gelling agent. In addition, many studies elucidate that polysaccharides isolated from plants have antioxidative activities [9]-[12].

Shaddock (Citrus grandis Osbeck) is an important economic fruit in Taiwan during autumn. Our preliminary study indicated that the outer seed coat of shaddock contained a high amount of transparent gel-like mucilage (MSS) and had never been studied before. In general, the seeds are removed and discarded while the pulp is eaten. The objective of this paper was to characterize MSS with respect to its physicochemical properties such as the viscosity, water holding capacity, antioxidative potency in vitro and cytotoxicity against the mouse embryo fibroblast (NIH 3T3) cells. Such information contributes toward the sustainable reuse of agricultural wastes and imparts the potential usefulness of MSS to various applications.

\section{Materials and Methods}

\subsection{Shaddock Seeds}

The seeds were removed from ripe shaddock fruits (Citrus grandis Osbeck) that were purchased from a local market in the northern Taiwan. After being dried at room temperature, they were stored in a desiccator box until use.

\subsection{Ruthenium Staining}

The dried seeds were imbibed in water for about $15 \mathrm{~min}$ to form a gel around wetted seed. Then, they were incubated with the cationic dye ruthenium $(2 \mathrm{~g} / \mathrm{L})$.

\subsection{Preparation of the Mucilage}

The dried seeds were extracted three times with water (water to seed ratio of 5:1) on a reciprocal shaker (BT-150, Yihdern, Taiwan) under the room temperature for 20 min each time. The extracts were mixed and vacuum filtrated through a glass microfibre filter (Whatman GF/A, GE Healthcare, USA). The filtrate was lyophilized in a freeze dryer (DM-25ES, VirTis, NY, USA). The dry MSS yield was estimated.

\subsection{Quantitative Analysis}

Ash content was determined using the AOAC oven method [13]. Total neutral sugar was determined by the phenol-sulphuric acid method [14] using glucose $(10-80 \mu \mathrm{g})$ as the standard. Uronic acid analysis followed the method of Blumenkrantz and Asboe-Hason [15], using phenolic m-hydroxydiphenyl reagent and calibrated against a standard glucouronic acid $(25-150 \mu \mathrm{g})$. Total protein was determined using the Bio-Rad protein micro-assay, with bovine serum albumin $(2-20 \mu \mathrm{g})$ as the standard. Total phenolic content was determined by Folin Ciocalteu reagent [16]. Briefly, $0.1 \mathrm{ml}$ solution of MSS in methanol (80\%) was mixed with $0.5 \mathrm{ml}$ of Folin Ciocalteu reagent (diluted 10 -fold with water) and $0.4 \mathrm{ml}$ of aqueous $\mathrm{Na}_{2} \mathrm{CO}_{3}(75 \mathrm{~g} / \mathrm{L})$. The mixture was kept for 
30 min in the dark and the total phenol content was determined at $765 \mathrm{~nm}$ with gallic acid (25 - $300 \mu \mathrm{g})$ as the standard.

\subsection{Viscosity Analysis}

The viscosities of MSS solutions ( 1 - $10 \mathrm{~g} / \mathrm{L}$ ) were measured using Dial Reading viscometer (LVT, Brookfield, Massachusetts, USA) with spindle No. 18 at $26^{\circ} \mathrm{C}$. The viscosities of xanthan $(1-5 \mathrm{~g} / \mathrm{L})$ and gum arabic $(1-10$ g/L) were compared.

\subsection{Water Holding Capacity (WHC) Analysis}

The WHC of MSS was determined by an adaptation of the filtration method of Robertson and Eastwood [17]. Briefly, a dry sample of $25 \mathrm{mg}$ was soaked in $10 \mathrm{~mL}$ water and shaken with an orbital shaker (200 rev/min) at room temperature for $24 \mathrm{~h}$ and filtered through filter paper (ADVANTEC No. 1, Tokyo, Japan). After $10 \mathrm{~min}$, the sample with the paper was weighed (wet weight) before drying at $60^{\circ} \mathrm{C}$ until a constant weight (dry weight) was obtained. The difference of the two weights gave WHC.

\subsection{Determination of Antioxidant Activity}

The antioxidant activity of the MSS was evaluated by using the DPPH free radical scavenging method described by Yamaguchi et al. [18], chelating ferrous methods according to Dinis et al. [19], and superoxide anion radical scavenging using the method of Li et al. [20], with slight modifications.

Briefly, $20 \mu \mathrm{L}$ of the MSS or butylated hydroxytoluene (BHT) at various concentrations were mixed with 100 $\mathrm{mM}$ Tris-HCl buffer ( $\mathrm{pH} 7.4,80 \mu \mathrm{L}$ ), and added to $100 \mu \mathrm{L}$ DPPH radical in ethanol $(0.25 \mathrm{mM})$. The mixture was shaken vigorously and left to stand for $20 \mathrm{~min}$ at room temperature in the dark. The absorbance was measured at $517 \mathrm{~nm}$. The percentage of DPPH radical scavenging activity was calculated as [( $\left.\left.A_{0}-A_{1}\right)\right] / A_{0} \times 100$, in which $A_{0}$ is the absorbance of the control, and $A_{1}$ is the absorbance of the MSS and BHT.

For chelating effect determination, briefly, $100 \mu \mathrm{L}$ of the MSS or EDTA at various concentrations were mixed with $2 \mathrm{mM}$ ammonium ferrous sulphate $(10 \mu \mathrm{L})$. The reaction was initiated by the addition of $5 \mathrm{mM}$ ferrozine $(20 \mu \mathrm{L})$ and the mixture was shaken vigorously and left standing at room temperature for $10 \mathrm{~min}$, and the absorbance of the mixture was determined at $562 \mathrm{~nm}$. The percentage of inhibition of ferrozine-ferrous complex formation was calculated by $\left[\left(A_{0}-A_{1}\right)\right] / A_{0} \times 100$, in which the notations of $A_{0}$ is the absorbance of the control, and $\mathrm{A} 1$ is the absorbance of the MSS and EDTA.

For superoxide anion radical scavenging determination, $100 \mu \mathrm{L}$ of the MSS or ascorbic acid at various concentrations were mixed with $100 \mu \mathrm{L}$ NBT solution $(300 \mu \mathrm{M}), 100 \mu \mathrm{L}$ PMS solution $(120 \mu \mathrm{M})$, and $100 \mu \mathrm{L}$ NADH solution $(936 \mu \mathrm{M})$. The mixture was shaken vigorously and left to stand for $5 \mathrm{~min}$ at room temperature in the dark, and the absorbance of the mixture was determined at $560 \mathrm{~nm}$. The percentage of superoxide anion radical scavenging activity was calculated as $\left[\left(\mathrm{A}_{0}-\mathrm{A}_{1}\right) / \mathrm{A}_{0}\right] \times 100$, in which $\mathrm{A}_{0}$ is the absorbance of the control, and $A_{1}$ is the absorbance of the MSS and ascorbic acid.

\subsection{Cell Viability Assay}

Mouse embryonic fibroblasts (cell line NIH 3T3, BCRC 60071) were purchased from the Bioresource Collection and Research Centre in Hsinchu (Taiwan).

NIH-3T3 cells $\left(1 \times 10^{4} /\right.$ well $)$ in their exponential growth phase were cultured in Dulbecco's modified Eagle's medium containing $10 \%$ fetal bovine serum and $5 \% \mathrm{CO}_{2}$ at $37^{\circ} \mathrm{C}$. Following a $12 \mathrm{~h}$ incubation period, the cells were exposed to various concentrations (5 - $300 \mathrm{mg} / \mathrm{L}$ ) of the MSS solution that was filtrated through a filter (PTF205030, BIOFIL, Guangzhou, China) for another $12 \mathrm{~h}$. The viability of cells was assessed using the MTT assay as described elsewhere. Briefly, the medium was aspirated and MTT was added to cells at a concentration of $0.25 \mathrm{~g} / \mathrm{L}$. Cells were incubated at $37^{\circ} \mathrm{C}$ for $3 \mathrm{~h}$ and the formazan product was solubilized with dimethylsulfoxide. The absorbance was detected in the microplate reader at $570 \mathrm{~nm}$. Concanavalin A (ConA) $(5 \mu \mathrm{g} / \mathrm{mL})$ was the positive control.

\subsection{Statistical Analysis}

The results are presented as means of at least three replicates \pm standard error (SE). The data were subjected to 
one-way ANOVA and the differences between means were measured at the 5\% probability level using Fisher's protected least significant difference (LSD) test (CoHort Software, Monterey, CA, USA).

\section{Results and Discussion}

\subsection{Preliminary Characterizations}

After imbibition at room temperature for $15 \mathrm{~min}$, the transparent gel-like mucilage appeared at the surrounding of seed coat, and its thickness was approximately 30\% of the seed width at the middle of its length (Figure 1(A)). It was significantly stained by ruthenium red (Figure 1(B)), revealing that MSS was an acidic polysaccharide.

A simple aqueous extraction process could obtain MSS. The yield of MSS was approximately $3.5 \%$ of the dry mass of the whole seed (Table 1), and its level was higher than that of flax seeds (about 2\%) [21], but lower than that of yellow mustard seeds (about 5\%) [22]. The major constituents were neutral sugar and uronic acid, $33.5 \%$ and $49.6 \%$, respectively (Table 1). These results are consistent with the ruthenium red staining (Figure $1(B))$. The ash content of $4.9 \%$ was lower than those of sage seed gum (9.2\%) [23] and flaxseed gum (7.4\% 8.4\%) [24], but higher than those reported for locust bean gum (0.7\% - 1.5\%) [25] and gum arabic (2.7\% - 3.2\%)

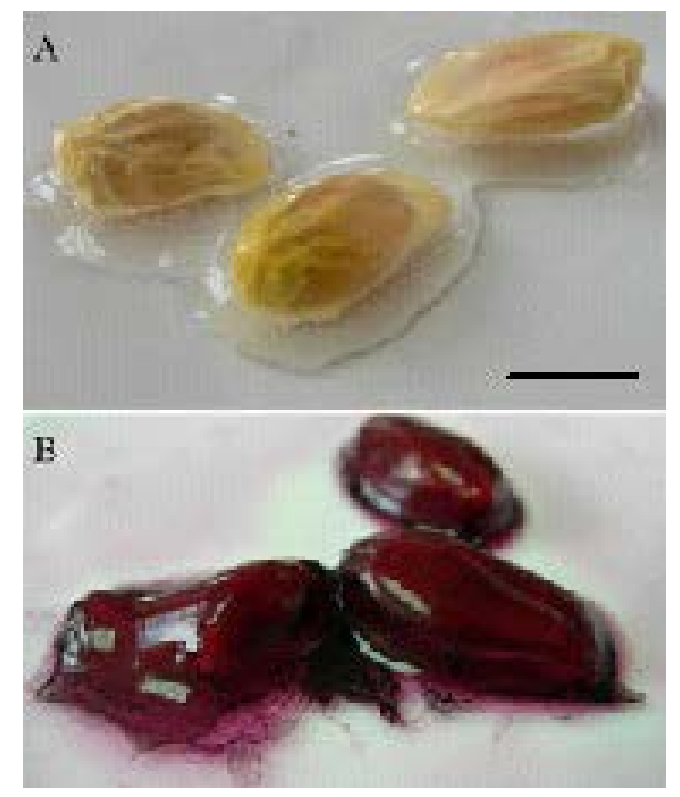

Figure 1. The appearance of shaddock seeds after been submerged in water (A) and stained with $0.2 \%(\mathrm{w} / \mathrm{v})$ ruthenium red (B). Bar is $1 \mathrm{~cm}$.

Table 1. The characteristics of MSS. The data were presented as mean \pm SE $(n=3)$. "Expressed as weight percent of dry seed.

\begin{tabular}{cc}
\hline Parameter & Quantity \\
\hline Yield $^{*}$ & $3.5 \% \pm 0.4 \%$ \\
Ash & $5.00 \% \pm 0.06 \%$ \\
Neutral sugar & $33.5 \% \pm 0.6 \%$ \\
Uronic acid & $49.6 \% \pm 2.8 \%$ \\
Protein & $0.7 \% \pm 0.1 \%$ \\
Total phenol & $0.2 \% \pm 0.0 \%$ \\
\hline
\end{tabular}


[26]. By contrast, the protein and the total phenol contents were both minor, only $0.7 \%$ and $0.2 \%$, respectively (Table 1).

\subsection{The Physical Characteristics}

MSS was effective at increasing the viscosity of solutions at levels as low as $5-10 \mathrm{~g} / \mathrm{L}$, reached to $1660 \mathrm{cP}$ at 10 g/L (Figure 2). Xanthan and gum arabic had high and low viscosity [27], showing $1455 \mathrm{cP}$ at $5 \mathrm{~g} / \mathrm{L}$ and only 1.6 $\mathrm{cP}$ at $10 \mathrm{~g} / \mathrm{L}$, respectively (Figure 2). Wannerbergera et al. [28] reported that the viscosity range of $10 \mathrm{~g} / \mathrm{L}$ solutions of linseed mucilage from 23 varieties was 20 - $280 \mathrm{cP}$ at room temperature. Hence, this moderate consistency offers the potential applications of MSS.

Similar to the trend of viscosity, the WHC analysis reveals that MSS could hold 44 times their weight of water (Table 2). This capacity was significantly lower than that of xanthan (274 times) but higher than that of gum arabic (7.9 times), even though the levels between MSS and gum arabic were not statistically significant (P > 0.05) (Table 2). In addition, the WHC levels in the polysaccharides isolated from acorn fruit at 4.3 [29], and in some fibre-rich feedstuffs, such as rice bran, sweet potato vine, and Tofu residue at 2.4, 6.3, and 8.3, respectively [30], were all lower than that of MSS.

These WHC and viscosity features are consistent with MSS ecological and physiological roles, such as facilitation of seed hydration [3] [4], affect further dispersal of the seed [7].

\subsection{Antioxidant Activity in Vitro}

The stable DPPH radical is a widely adopted target for evaluating the free radical scavenging ability of various samples [31]. MSS showed a weak quenching activity against DPPH radical, by only inhibiting $15 \%$ at $400 \mathrm{~g} / \mathrm{L}$, significantly lower than BHT with $\mathrm{IC}_{50}$ value reaching $8.2 \mathrm{mg} / \mathrm{L}$ (Figure 3(A)). Guendez et al. [32] addressed that there was a positive relation between the activity of scavenging DPPH radical and the content of polyphenol

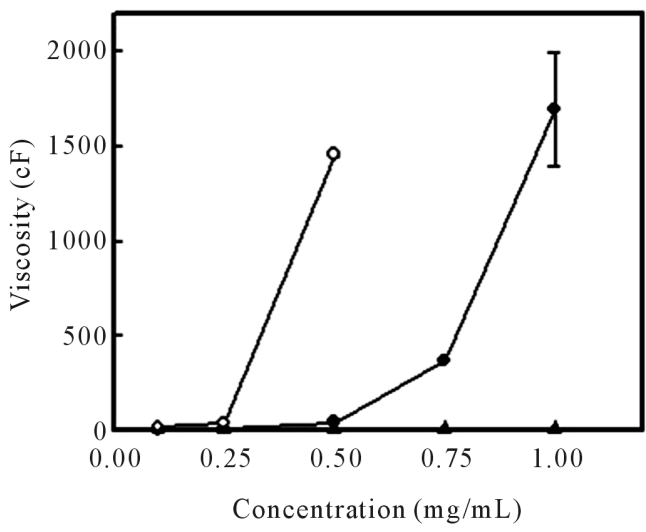

Figure 2. The viscosity of MSS (closed circles), xanthan (opened circles), and gum arabic (closed triangles) at different concentrations. The data were mean $\mathrm{cP} \pm \mathrm{SE}(\mathrm{n}=3)$.

Table 2. The water holding capacity of MSS, xanthan and gum arabic. The data were presented as mean $\pm \operatorname{SE}(n=3)$. Different lowercase letters show significant difference $(\mathrm{P}<0.05)$.

\begin{tabular}{cc}
\hline & $\begin{array}{c}\text { Water holding capacity } \\
\text { g of water/g DW }\end{array}$ \\
\hline Xanthan & $274.0 \pm 45.8^{\mathrm{a}}$ \\
MSS & $44.5 \pm 3.7^{\mathrm{b}}$ \\
Gum arabic & $7.9 \pm 1.6^{\mathrm{b}}$ \\
\hline
\end{tabular}



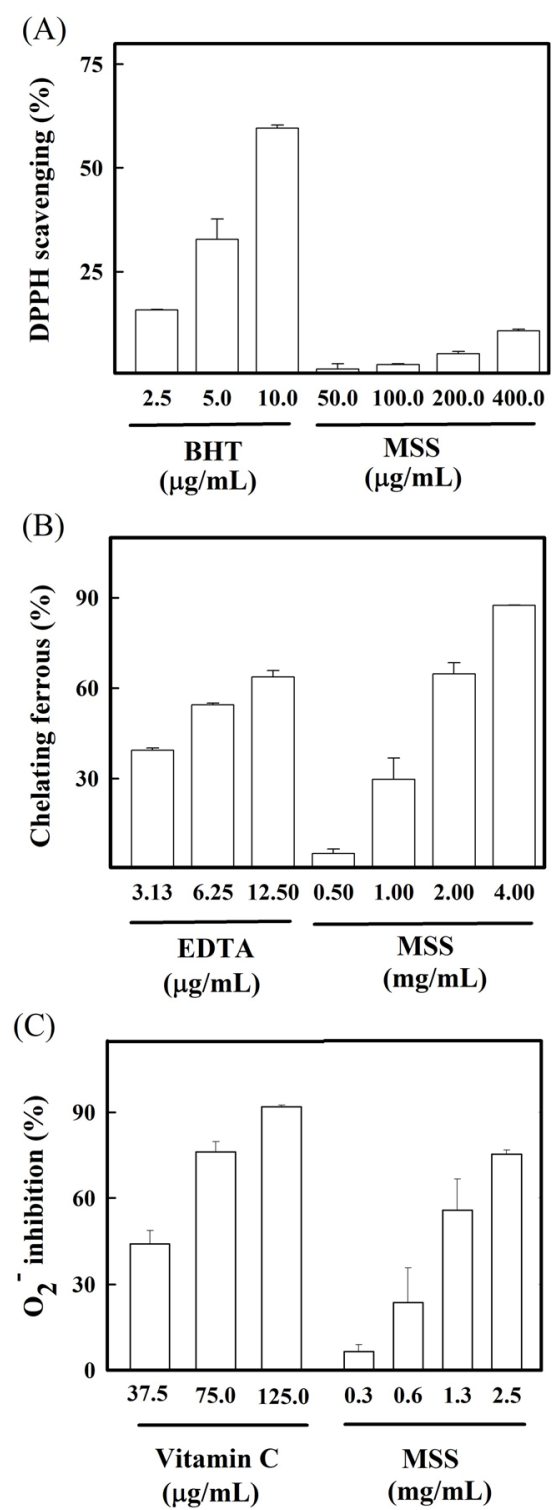

\begin{abstract}
Figure 3. The DPPH free radical scavenging (A), ferrous chelating (B), and superoxide anion radical scavenging (C) activities of MSS and the relative standards, butylated hydroxytoluene (BHT), EDTA and vitamin C, respectively. The data were presented as mean $\pm \operatorname{SE}(n=3)$.
\end{abstract}

in the seeds of different grape species. Hence, a weak free radical scavenging ability may be attributed to MSS to contain low levels of phenol (Table 1).

Iron is essential for oxygen transport, respiration and activity of many enzymes, which are required for sustaining life; however, ferrous, not ferric, is the most powerful pro-oxidant among the various species of metal ions and is able to generate free radicals from peroxides by the Fenton reaction to catalyze oxidative changes in lipids, proteins, and other cellular components [20] [33] [34]. There is a good correlation between chelating ferrous ability and uronic acid content in the polysaccharides from Zizyphus jujube [35]. MSS contained uronic acids (Table 1) and exhibited a moderate ferrous ion-chelating activity that increased on increasing concentration from 0.5 to $4.0 \mathrm{~g} / \mathrm{L}$, even though its $\mathrm{IC}_{50}$ value was $1.5 \mathrm{~g} / \mathrm{L}$, not comparable with EDTA $\left(\mathrm{IC}_{50}=6.2 \mathrm{mg} / \mathrm{L}\right)$ (Figure 3(B)). The results indicated that MSS could act moderately as a ferrous chelator to minimize moderately the harmful oxidation induced by ferrous ion. 


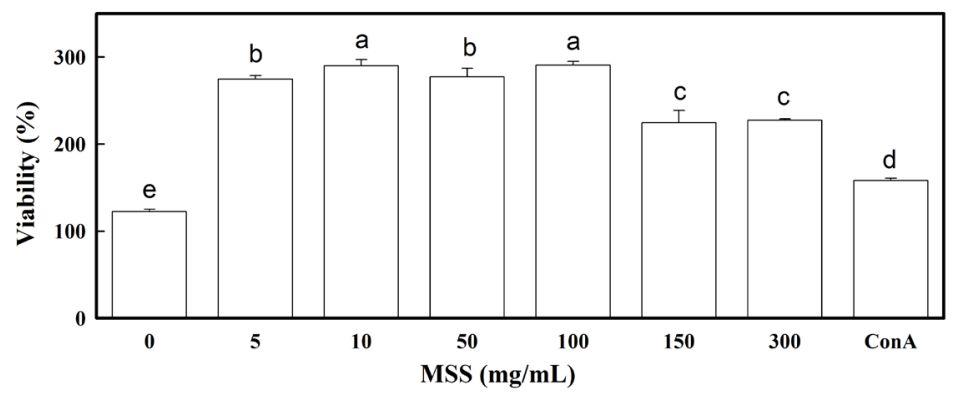

Figure 4. NIH 3 T3 cells were exposed to various concentrations of MSS. The data were presented as mean \pm SE $(n=3)$. Different lowercase letters show significant difference $(\mathrm{P}<0.05)$.

Of the reactive oxygen species, superoxide anion radical is generated first [20]. Superoxide anion radical decomposes to form others reactive oxygen species, such as singlet oxygen, hydroxyl radicals and hydrogen peroxide [36]. Therefore, its scavenging is very important to evaluate the antioxidant efficiency of various samples. Figure 3(C) shows the dose-dependent curve for the superoxide anion radical scavenging activity of MSS and its $\mathrm{IC}_{50}$ value was $1.1 \mathrm{~g} / \mathrm{L}$, even though that was markedly lower than Vitamin C $\left(\mathrm{IC}_{50}=49.0 \mathrm{mg} / \mathrm{L}\right)$.

\subsection{Cell Viability}

MTT assay showed that MSS significantly stimulated the viability of mouse skin fibroblast NIH3T3 at 5 - 300 $\mathrm{mg} / \mathrm{L}$, reached to $130 \%$ increase at $100 \mathrm{mg} / \mathrm{L}$, and the increasing efficiency was profoundly higher than ConA, which had only $20 \%$ increase, a value much lower than that of MSS (116\%) at the same concentration (5 mg/L) (Figure 4). Fibroblasts are important in supporting normal wound healing, and increasing the number of fibroblasts in an artificial dermal substitute is conducive to improved healing in experimental wounds [37]. Therefore, it is worthwhile to study whether MSS has the potential to be used on healing skin wounds.

\section{Conclusion}

The present work clearly demonstrated that MSS could be easily obtained via a simple extraction process from the outer layer seed of shaddock, and its yield was about 3.5\% of the dry seed. MSS exhibited a moderate viscosity, water holding capacity, and ferrous ion-chelating as well as superoxide anion radical scavenging activities. MSS not only showed nontoxicity, but also stimulated the proliferation of NIH3T3 cells. These results impart the potential usefulness of MSS to food, cosmetics and other value-added applications. Several kinds of seed coat mucilage present in different plants, hence, another important subject will understand the composition and linkage of the purified MSS and further identify its polysaccharide type.

\section{Acknowledgements}

The authors would like to thank Professor Jong-Ching Su for helpful comments on drafting this manuscript and Associate Professor Jer-Chia Chang (Department of Horticulture, National Chung Hsing University) for identifying the species of shaddock. This work was supported by the grant NSC 101-2311-B-390-001 from the National Science Council, Executive Yuan, Taiwan.

\section{References}

[1] Van Caeseele, L., Mills, J.T., Sumner, M. and Gillespie, R. (1981) Cytology of Mucilage Production in the Seed Coat of Candle Canola (Brassica campestris). Canadian Journal of Botany, 59, 292-300. http://dx.doi.org/10.1139/b81-042

[2] Boesewinkel, F.D. and Bouman, F. (1995) The Seed: Structure and Function. In: Kigel, J. and Galili, G., Eds., Seed Development and Germination, Marcel Dekker, Inc., New York, 1-24.

[3] Harper, J.L. and Benton, R.A. (1966) The Behaviour of Seeds in Soil II. The Germination of Seeds on the Surface of a Water Supplying Substrate. Journal of Ecology, 54, 151-166. http://dx.doi.org/10.2307/2257664

[4] Sun, Y., Tan, D.Y., Baskin, C.C. and Baskin, J.M. (2012) Role of Mucilage in Seed Dispersal and Germination of the Annual Ephemeral Alyssum minus (Brassicaceae). Australian Journal of Botany, 60, 439-449. 
http://dx.doi.org/10.1071/BT11314

[5] Huang, Z.Y., Boubriak, I., Osborne, D.J., Dong, M. and Gutterman, Y. (2008) Possible Role of Pectin-Containing Mucilage and Dew in Repairing Embryo DNA of Seeds Adapted to Desert Conditions. Annals of Botany, 101, 277-283. http://dx.doi.org/10.1093/aob/mcm089

[6] Gutterman, Y., Witztum, A. and Heydecker, W. (1973) Studies on the Surfaces of Desert Plant Seeds. II. Ecological Adaptations of the Seeds of Blepharis persica. Annals of Botany, 37, 1051-1055.

[7] Huang, Z., Gutterman, Y. and Osborne, D.J. (2004) Value of the Mucilaginous Pellicle to Seeds of the Sand-Stabilizing Desert Woody Shrub Artemisia sphaerocephala (Asteraceae). Trees, 18, 669-676. http://dx.doi.org/10.1007/s00468-004-0349-4

[8] Zhao, G. H., Kan, J.Q., Li, Z.X. and Chen, Z.D. (2005) Structural Features and Immunological Activity of a Polysaccharide from Dioscorea opposita Thunb Roots. Carbohydrate Polymers, 61, 125-131. http://dx.doi.org/10.1016/j.carbpol.2005.04.020

[9] Hu, Y., Xu, J. and Hu, Q.H. (2003) Evaluation of Antioxidant Potential of Aloe vera (Aloe barbadensis Miller) Extracts. Journal of Agricultural and Food Chemistry, 51, 7788-7791. http://dx.doi.org/10.1021/jf034255i

[10] Jiang, Y.H., Jiang, X.L., Wang, P. and Hu, X.K. (2005) In Vitro Antioxidant Activities of Water-Soluble Polysaccharides Extracted from Isaria farinosa B05. Journal of Food Biochemistry, 29, 323-335. http://dx.doi.org/10.1111/j.1745-4514.2005.00040.X

[11] Chen, Y., Xie, M.Y., Nie, S.P., Li, C. and Wang, Y.X. (2008) Purification, Composition Analysis and Antioxidant Activity of a Polysaccharide from the Fruiting Bodies of Ganoderma atrum. Food Chemistry, 107, 231-241. http://dx.doi.org/10.1016/j.foodchem.2007.08.021

[12] Xie, J.H., Xie, M.Y., Nie, S.P., Shen, M.Y., Wang, Y.X. and Li, C. (2010) Isolation, Chemical Composition and Antioxidant Activities of a Water-Soluble Polysaccharide from Cyclocarya paliurus (Batal.) Iljinskaja. Food Chemistry, 119, 1626-1632. http://dx.doi.org/10.1016/j.foodchem.2009.09.055

[13] AOAC (1980) Official Methods of Analysis. 13th Edition, Association of Official Analytical Chemists, Washington DC.

[14] Dubois, M., Gilles, K.A., Hamilton, J.K., Rebers, P.A. and Smith, F. (1956) Colorimetric Method for Determination of Sugars and Related Substances. Analytical Chemistry, 28, 350-356. http://dx.doi.org/10.1021/ac60111a017

[15] Blumenkrantz, N. and Asboe-Hansen, G. (1973) New Method for Quantitative Determination of Uronic Acids. Analytical Biochemistry, 54, 484-489. http://dx.doi.org/10.1016/0003-2697(73)90377-1

[16] Scalbert, A., Monties, B. and Janin, G. (1989) Tannins in Wood: Comparison of Different Estimation Methods. Journal of Agricultural and Food Chemistry, 37, 1324-1329. http://dx.doi.org/10.1021/jf00089a026

[17] Robertson, J.A. and Eastwood, M.A. (1981) An Investigation of the Experimental Conditions Which Could Affect Water-Holding Capacity of Dietary Fibre. Journal of the Science of Food and Agriculture, 32, 819-825. http://dx.doi.org/10.1002/jsfa.2740320811

[18] Yamaguchi, T., Takamura, H., Matoba, T. and Terao, J. (1988) HPLC Method for Evaluation of the Free Radical Activity of Food by Using 1,1-Diphenyl-2-picrylhydrazyl. Bioscience Biotechnology and Biochemistry, 62, 1201-1204. http://dx.doi.org/10.1271/bbb.62.1201

[19] Dinis, T.C.P., Maderia, V.M.C. and Almeida, L.M. (1994) Action of Phenolic Derivatives (Acetaminophen, Salicylate, and 5-Aminosalicylate) as Inhibitor of Membrane Lipid Peroxidation and as Peroxyl Radical Scavengers. Archives of Biochemistry and Biophysics, 315, 161-169. http://dx.doi.org/10.1006/abbi.1994.1485

[20] Li, X.L., Zhou, A.G. and Han, Y. (2006) Anti-Oxidation and Anti-Microorganism Activities of Purification Polysaccharide from Lygodium japonicum in Vitro. Carbohydrate Polymers, 66, 34-42. http://dx.doi.org/10.1016/j.carbpol.2006.02.018

[21] Naran, R., Chen, G. and Carpita, N.C. (2008) Novel Rhamnogalacturonan I and Arabinoxylan Polysaccharides of Flax Seed Mucilage. Plant Physiology, 148, 132-141. http://dx.doi.org/10.1104/pp.108.123513

[22] Cui, W., Eskin, N.A.M. and Biliaderis, C.G. (1993) Chemical and Physical Properties of Yellow Mustard (Sinapis alba L.) Mucilage. Food Chemistry, 46, 169-176. http://dx.doi.org/10.1016/0308-8146(93)90032-B

[23] Razavi, S.M.A., Cui, S.W., Guo, Q.B. and Ding, H.H. (2014) Some Physicochemical Properties of Sage (Salvia macrosiphon) Seed Gum. Food Hydrocolloids, 35, 453-462. http://dx.doi.org/10.1016/j.foodhyd.2013.06.022

[24] Cui, W. and Mazza, G. (1996) Physicochemical Characteristics of Flaxseed Gum. Food Research International, 29, 397-402. http://dx.doi.org/10.1016/0963-9969(96)00005-1

[25] Dakia, P.A., Bleckerb, C., Roberta, C., Watheleta, B. and Paquot, M. (2008) Composition and Physicochemical Properties of Locust Bean Gum Extracted from Whole Seeds by Acid or Water Dehulling Pre-Treatment. Food Hydrocolloids, 22, 807-818. http://dx.doi.org/10.1016/j.foodhyd.2007.03.007 
[26] Lelon, J.K., Jumba, I.O., Keter, J.K., Chemuku, W. and Oduor, F.D.O. (2010) Assessment of Physical Properties of Gum Arabic from Acacia senegal Varieties in Baringo District, Kenya. African Journal of Plant Science, 4, 95-98.

[27] Mazza, G. and Biliaderis, C.G. (1989) Functional Properties of Flax Seed Mucilage. Journal of Food Science, 54, 1302-1305. http://dx.doi.org/10.1111/j.1365-2621.1989.tb05978.x

[28] Wannerbergera, K., Nylandera, T. and Nymanb, M. (1991) Rheological and Chemical Properties of Mucilage in Different Varieties from Linseed (Linum usitatissimum). Acta Agriculturae Scandinavica, 41, 311-319. http://dx.doi.org/10.1080/00015129109439914

[29] Tadayoni, M., Sheikh-Zeinoddin, M. and Soleimanian-Zad, S. (2015) Isolation of Bioactive Polysaccharide from Acorn and Evaluation of Its Functional Properties. International Journal of Biological Macromolecules, 72, 179-184. http://dx.doi.org/10.1016/j.ijbiomac.2014.08.015

[30] Ngoc, T.T.B., Len, N.T. and Lindberg, J.E. (2012) Chemical Characterization and Water Holding Capacity of Fibre-Rich Feedstuffs Used for Pigs in Vietnam. Asian-Australasian Journal of Animal Sciences, 25, 861-868. http://dx.doi.org/10.5713/ajas.2011.11294

[31] Lee, S.E., Hwang, H.J., Ha, J.S., Jeong, H.S. and Kim, J.H. (2003) Screening of Medicinal Plant Extracts for Antioxidant Activity. Life Science, 73, 167-179. http://dx.doi.org/10.1016/S0024-3205(03)00259-5

[32] Guendez, R., Kallithraka, S., Makris, D.P. and Kefalas, P. (2005) Determination of Low Molecular Weight Polyphenolic Constituents in Grape (Vitis vinifera sp.) Seed Extracts: Correlation with Antiradical Activity. Food Chemistry, 89, 1-9. http://dx.doi.org/10.1016/j.foodchem.2004.02.010

[33] Wu, C., Chen, F., Wang, X., Kim, H.J., He, G.Q., Haley-Zitlin, V. and Huang, G. (2006) Antioxidant Constituents in Feverfew (Tanacetum parthenium) Extract and Their Chromatographic Quantification. Food Chemistry, 96, 220-227. http://dx.doi.org/10.1016/j.foodchem.2005.02.024

[34] Alia, E.M., Somayyeh, E. and Bahman, E. (2009) Sambucus ebulus Elburensis Fruits: A Good Source for Antioxidants. Pharmacognosy Magazine, 4, 213-218.

[35] Changa, S.C., Hsua, B.Y. and Chena, B.H. (2010) Structural Characterization of Polysaccharides from Zizyphus jujuba and Evaluation of Antioxidant Activity. International Journal of Biological Macromolecules, 47, 445-453. http://dx.doi.org/10.1016/j.ijbiomac.2010.06.010

[36] Korycka-Dahl, M. and Richardson, T. (1978) Photogeneration of Superoxide Anion in Serum of Bovine Milk and in Model Systems Containing Riboflavin and Amino Acids. Journal of Dairy Science, 61, 400-407. http://dx.doi.org/10.3168/jds.S0022-0302(78)83613-3

[37] Ghafourian, M., Tamri, P. and Hemmati, A. (2015) Enhancement of Human Skin Fibroblasts Proliferation as a Result of Treating with Quince Seed Mucilage. Jundishapur Journal of Natural Pharmaceutical Products, 10, e18820. http://dx.doi.org/10.17795/jjnpp-18820 